\title{
Nutritional, behavioral and performance parameters of F1 Holstein x Zebu cows at different lactation stages
}

\author{
[Parâmetros nutricionais, comportamento ingestivo e desempenho de vacas F1
} Holandês $x$ Zebu em diferentes estádios da lactação]

\author{
P.F. Santana, V.R. Rocha Júnior, F.P. Monção*, J.R.M. Ruas, L.A. Borges, J.C.P. Ramos, \\ F.F. Hora, M.C. Oliveira, E.C.J. Sales, C.C.S. Carvalho, M.D. Costa, M.F.P. Silva
}

Universidade Estadual de Montes Claros - Janaúba, MG

\begin{abstract}
The objective of this study was to evaluate the different lactation stages of F1 Holstein x Zebu cows on intake and digestibility of nutrients, nitrogen use efficiency, feeding behavior and performance. Thirty-six F1 Holstein $\times$ Zebu cows with initial body weight (BW) of $482 \pm 43 \mathrm{~kg}$ were used. The early, mid and late lactation stages were characterized after $50 \pm 13,111.5 \pm 11.75$ and $183.0 \pm 17.5$ days in milk, respectively. A completely randomized design with three lactation stages and 12 cows in each treatment group was used. Dry matter intake $(\mathrm{P}=0.01)$ was higher in late lactation. Milk yield $(\mathrm{P}<0.01)$ was $24.17 \%$ higher in early lactation than in other stages. Body weight was lowest in mid-lactation cows $(465.63 \mathrm{~kg}$; $\mathrm{P}<0.01)$. The feed efficiency was $23.36 \%$ higher in early lactation than in other stages $(0.82 \mathrm{~kg}$ of milk/kg of DM). F1 Holstein $\mathrm{x}$ Zebu cows have increased dry matter intake in late lactation. Milk yield and feed efficiency in early lactation were benefited by changes in feeding behavior, such as increased rumination time.
\end{abstract}

Keywords: crossbreeding, dairy cattle, daily milk yield, feeding behavior, nitrogen balance

\section{RESUMO}

O objetivo deste estudo foi avaliar os diferentes estágios de lactação de vacas F1 Holandês x Zebu quanto ao consumo e à digestibilidade de nutrientes, à eficiência no uso de nitrogênio, ao comportamento ingestivo e ao desempenho. Trinta e seis vacas F1 Holandês $\times$ Zebu, com peso corporal inicial $(P C)$ de $482 \pm 43 \mathrm{~kg}$, foram

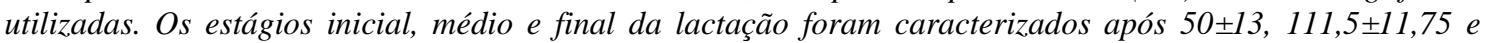
$183,0 \pm 17,5$ dias de lactação, respectivamente. $O$ arranjo experimental adotado foi o delineamento inteiramente ao acaso, com três fases de lactação e 12 vacas em cada grupo de tratamento. O consumo de matéria seca $(P=0,01)$ foi maior no período final da lactação. Na fase inicial da lactação, a produção de leite $(P<0,01)$ foi maior em 24,17\% em comparação às demais fases. Na fase intermediária da lactação, as vacas apresentaram menor peso corporal $(465,63 \mathrm{~kg} ; \mathrm{P}<0,01)$ em relação às demais fases. A eficiência alimentar foi maior em 23,36\% na fase inicial da lactação (0,82kg de leite/kg de MS). Vacas F1 Holandês x Zebu aumentam o consumo de matéria seca no período final da lactação. A produção de leite e a eficiência alimentar no início da lactação foram favorecidas por mudanças no comportamento ingestivo, como o aumento do tempo de ruminação.

Palavras-chave: cruzamento, gado leiteiro, produção diária de leite, comportamento ingestivo, balanço de nitrogênio

\section{INTRODUCTION}

Brazil ranks fourth in the world in terms of milk production, with a total of 34.23 billion liters produced in 2016 (Anuário..., 2018). Despite its high production, the national productivity of 1,600 liters per cow per year is lower than the world average (3,500 liters). Most farmers have chosen to use crossbred Holstein $\mathrm{x}$ Zebu cows aiming to alleviate the challenges posed by tropical climate to dairy production. Crossbred cows are responsible for about $80 \%$ of the volume of milk produced in the country (Salgado et al., 2016); their characteristics and rusticity (beneficial effects of heterosis) allow flexibility in managing pasture-based milk production systems

Recebido em 21 de agosto de 2019

Aceito em 17 de dezembro de 2019

*Autor para correspondência (corresponding author)

E-mail: moncaomoncao@yahoo.com.br 
during the summer. On the other hand, in the winter, diets are provided in feed troughs due to shortage of forage caused by seasonality of forage production (Santos et al., 2012; Borges et al., 2019; Monção et al., 2019), especially in semiarid conditions of Brazil.

The economic results of pasture-based systems can be competitive compared with more intensive systems since feeding represents the most significant costs in dairy production. Moreover, the economic results are dependent on the lactation curve of the animals, characterized by the productivity of cows during lactation (Silva et al., 2019). According to Daltro et al. (2019) and Santos et al. (2014), understanding the dynamics of lactation as well as nutrient intake in crossbred cows at different lactation stages is fundamental in genetic breeding programs because it allows selecting efficient animals. Furthermore, Daltro et al. (2019) emphasize that nutrient intake and lactation curve may vary between and within breeds throughout the lactation cycle due to the effect of heterosis.

Therefore, understanding nutrient intake and digestibility, as well as nutrient use efficiency, feeding behavior and performance of cows at the different lactation stages is an important tool to aid the development of improved management strategies. However, few studies evaluated these dynamics using crossbred F1 Holstein x Zebu cows under semi-arid conditions in Brazil. Based on the above, the objective was to evaluate the effect of different lactation stages on intake and digestibility of nutrients, nitrogen use efficiency, feeding behavior and performance of F1 Holstein $\mathrm{x}$ Zebu cows.

\section{MATERIAL AND METHODS}

All procedures involving animals were approved by the institutional committee on animal use (protocol number 138/2017). The study was carried out at an experimental farm in the municipality of Janaúba, Brazil, at the following geographical coordinates: $43^{\circ} 16^{\prime} 18.2$ "W and $15^{\circ} 49^{\prime} 51.5^{\prime \prime} \mathrm{S}$.

Thirty-six F1 Holstein $\times$ Zebu cows with initial body weight $(\mathrm{BW})$ of $482 \pm 43 \mathrm{~kg}$ (mean \pm SEM) and mean age of 6 years were used. The early, mid and late lactation stages were characterized after $50 \pm 13,111.5 \pm 11.75$ and $183.0 \pm 17.5$ days in milk or postpartum, respectively. A completely randomized design with three lactation stages (early, mid and late) and 12 cows in each treatment group was used. The cows were evaluated for five consecutive days at each lactation stage (early, mid and late). The cows received the same diet throughout the experimental period (Table 1), which was based on the body weight of each cow, maintaining a forage: concentrate ratio of 75:25 (dry matter basis). The diets were offered twice a day, at 8:00 a.m. and at 3:00 p.m. as a Total Mixed Ration (TMR).

Table 1. Chemical composition of ingredients and diet during the experimental period

\begin{tabular}{llll}
\multicolumn{1}{c}{ Item $(\mathrm{g} / \mathrm{kg} \mathrm{DM})^{1}$} & \multicolumn{1}{c}{ Corn silage } & \multicolumn{1}{c}{ Concentrate } & Diet $^{2}$ \\
& & & \\
\hline Dry matter & & & 608.54 \\
Organic matter & 502.74 & 925.92 & 952.09 \\
Crude protein & 962.02 & 922.31 & 105.84 \\
NDIN & 68.37 & 218.25 & 7.55 \\
ADIN & 5.99 & 12.24 & 0.78 \\
Ether extract & 0.79 & 0.75 & 27.9 \\
Non-fiber carbohydrates & 27.77 & 28.28 & 320.09 \\
NDFap & 302.89 & 371.68 & 498.26 \\
Acid detergent fiber & 562.98 & 304.1 & 243.43 \\
Lignin & 300.5 & 72.21 & 82.63 \\
Total digestible nutrients* & 99.58 & 31.75 & 605.03 \\
\hline
\end{tabular}

${ }^{1}$ Nutrient on dry basis (grams per kilogram) - DM - Dry matter; NDIN - neutral detergent insoluble nitrogen; ADIN acid detergent insoluble nitrogen; NDFap - neutral detergent fiber corrected for ash and protein; * National research council - NRC (Nutrient..., 2001). ${ }^{2}$ Diet with $75 \%$ of roughage and $25 \%$ of concentrate. 
The TMR contained corn silage as the forage source, which was weighed daily and then mixed to the concentrate. The cows were kept in pens of $16 \mathrm{~m}^{2} /$ animal equipped with feeding troughs (1 linear meter) and drinkers (individual capacity of 200 liters). Cows were milked by mechanical milking twice a day, at 7:00 a.m. and 2:00 p.m., in the presence of their calves to stimulate milk letdown. Immediately after milking, calves remained with the cows and were allowed to suckle the residual milk.

The intake was evaluated daily by weighing the feed supplied and refusals. Samples of diets and refusals (5-day sampling) were stored at $-20^{\circ} \mathrm{C}$ for further analysis. Samples of diets, concentrate ingredients, refusals, and feces were analyzed to evaluate feed intake and digestibility. The samples were analyzed for dry matter (DM; method 967.03), ash (method 942.05), CP (CP; method 981.10), and ether extract (EE; method 920.39) according to recommendations of the AOAC (Official..., 1990). The contents of neutral detergent fiber corrected for ash and protein (using heat-stable alpha-amylase without sodium sulfite) (NDFap; Mertens, 2002; Licitra et al., 1996) and acid detergent fiber (ADF) were determined as described by Van Soest et al. (1991), while lignin was determined by treating the acid detergent fiber residue with sulfuric acid at $72 \%$.

Non-fiber carbohydrate (NFC) contents were calculated as proposed by Detmann et al. (2012): NFC $(\mathrm{g} / \mathrm{kg})=100-$ ash - EE - NDFap - CP. The total digestible nutrients (TDN) were estimated using the equation proposed by NRC (Nutrient..., 2001). Samples of diets, concentrate ingredients, refusals, and feces were placed in non-woven fabric bags $\left(100 \mathrm{~g} / \mathrm{m}^{2}\right)$ and incubated in the rumen for $288 \mathrm{~h}$ for analyzing the indigestible neutral detergent fiber (iNDF) (Detmann et al., 2012; method INCT-CA F-008/1). Bags were incubated in the rumen of two rumen-cannulated crossbred steers weighing $480 \pm 30 \mathrm{~kg}$, with a mean age of 8 years. The following equation was used to determine the digestibility of each fraction: [ (amount of nutrient ingested - amount of nutrient excreted in the feces) $\mathrm{x} 100 \mathrm{~J} /$ amount of nutrient ingested.

Samples of milk from each animal were collected twice a day for five days at each lactation stage. The total amount of milk produced in the morning and afternoon was also evaluated. Milk quality was evaluated using composite samples formed by samples collected from each cow during morning and afternoon milking, after weighing the milk using a milk meter (Mark V®) Delaval Ltda). The samples were placed in plastic recipients $(50.0 \mathrm{~mL})$ containing preservative (Bronopol®). The levels of protein, fat, milk urea nitrogen (MUN) and total solids (in $\mathrm{g} / \mathrm{kg}$ of milk) were determined by infrared absorption spectrophotometry using a milk analyzer (Bentley 2000®; Bentley Instruments Inc.).

On day 3, blood samples were taken from the coccygeal vein using vacuum tubes containing sodium fluoride and potassium oxalate (Glistab® anticoagulant; Labtest Diagnóstica S.A., Lagoa Santa, Brazil) 4 hours after the morning feeding. The samples were centrifuged at 4.000rpm for $20 \mathrm{~min}$ and the serum obtained was stored in Eppendorf tubes and frozen at $-18{ }^{\circ} \mathrm{C}$ for further analysis. Plasma urea concentrations were determined by a colorimetric enzymatic method using commercial kits (Ureia 500, Doles ${ }^{\circledR}$ Reagents; Panamá, Brazil). Urine spot samples from all animals at each lactation stage were obtained during spontaneous urination on the $3^{\text {rd }}$ day of sample collection, approximately four hours after feeding. An aliquot of $10 \mathrm{~mL}$ of the urine sample was filtered and immediately diluted in $40 \mathrm{~mL}$ of $\mathrm{H}_{2} \mathrm{SO}_{4} 0.036 \mathrm{~N}$ for later analysis of urea and creatinine content, as described by Chizzotti et al. (2007).

The samples were then transferred to Eppendorf tubes and analyzed for urea content using the same methodology used to analyze blood samples. The end-point method was used to determine the creatinine content by means of picrate and acidification with enzymatic methods. Quantification of the daily urinary volume of each animal was calculated by multiplying the individual body weight by the amount of creatinine excreted daily and then dividing the product by the creatinine concentration $(\mathrm{mg} / \mathrm{L})$ in the spot sample. The mean value of $24.04(\mathrm{mg} / \mathrm{kg}$ BW) was used to calculate the total daily creatinine excretion (Chizzotti et al., 2007). Total daily urinary volume was estimated to calculate total urinary nitrogen. The amount of nitrogen ingested ( $\mathrm{N}$-ingested; g/day) and the amount of $\mathrm{N}$ excreted in the feces ( $\mathrm{N}$-feces; g/day), urine $(\mathrm{N}$ urine; g/day) and milk (N-milk; g/day) were used to calculate the nitrogen balance (NB). Dietary 
nitrogen use efficiency (NUE) was calculated by dividing the concentration of nitrogen retained in milk by nitrogen intake inkg/day. Feed efficiency was calculated by dividing the average milk yield (kg/day) by the DM intake (kg/day) (Valadares Filho et al., 2000).

The feeding behavior was assessed on the $4^{\text {th }}$ and $5^{\text {th }}$ day of sample collection at each lactation stage for 24 hours. At night, the environment was kept under artificial light. A 3-d adaptation period preceded sample collection to allow the animals to adapt to this condition. On the first day, visual observation of each animal was made every 5 minutes for 24 hours to determine the time spent feeding, rumination and resting according to Mezzalira et al. (2011). Total chewing time and number of ruminating chews per day were obtained according to Burger et al. (2000).

The milk yield (MY) of each cow at each lactation stage was recorded during the five days of sample collection. Milk yield was corrected to $3.5 \%$ fat content (FC) using the equation proposed by Sklan et al. (1992): $\mathrm{MY}_{3.5} \%=\mathrm{MY} \times(0.432+$ $0.163 \times$ FC). A mechanical scale was used to determine the body weight of cows (Valfran, Votuporanga, São Paulo, Brazil).

The initial weight of the animals was set at 10 days post-partum. The cows were weighed on the $5^{\text {th }}$ day of sample collection, after evaluation of feeding behavior. Body condition scores (BCS) were assessed weekly by a single technician at the beginning (initial weighing) and the $5^{\text {th }}$ day of collection at each lactation stage. A 1 to 5 scale with 0.10-point intervals was used to analyze the $\mathrm{BCS}$, in which 1 represents a very lean cow and 5 an obese cow (adapted from Mishra et al., 2016). The initial BCS of the cows was 3.65 \pm 0.10 .

The data were analyzed using SAS software version 9.0 (SAS/STAT..., 2008). The PROC UNIVARIATE procedure was used to detect outliers and check the normality of the residuals. Data were analyzed according to the following model: $\mathrm{Y}_{\mathrm{ij}}=\mu+\mathrm{LS}_{\mathrm{i}}+\mathrm{C}_{\mathrm{j}}+\mathrm{IBW}+\mathrm{e}_{\mathrm{k}(\mathrm{ij})}$; in which: $\mathrm{Y}$ $\mathrm{ij}=$ the $\mathrm{j}$-th observation on the $\mathrm{i}$-th treatment; $\mu=$ overall mean; $\mathrm{LC}_{\mathrm{i}}=$ effect of the $\mathrm{i}$-th lactation stage, with $\mathrm{i}=1,2$ and $3 ; \mathrm{C}_{\mathrm{j}}=$ effect of $\mathrm{j}$-th cow, with $\mathrm{j}=1,2$, 3, and 36; IBW=Initial body weight as a covariate; $\mathrm{e}_{\mathrm{k}(\mathrm{ij})}=$ experimental error associated with all observations ( $\left.\mathrm{Y}_{\mathrm{k}(\mathrm{ij})}\right)$, which is independent, assuming normal distribution with mean zero and variance $\delta_{2}$. The means at each lactation stage were compared by the StudentNewman-Keuls (SNK) test. Data are least-square mean values \pm standard error of the means (SEM) unless indicated otherwise. The mean values were considered different if $\mathrm{P}<0.10$.

\section{RESULTS}

Dry matter intake (DMI; $\mathrm{P}=0.01$ ) was higher in late lactation. The intakes of crude protein (CPI; $\mathrm{P}=0.93$ ) and neutral detergent fiber corrected for ash and protein (NDFap; $\mathrm{P}=0.78$ ) and the digestibility of non-fibrous carbohydrate (NFCD; $\mathrm{P}=0.56)$ and NDFap $(\mathrm{P}=0.14)$ were similar at different stages of lactation (Table 2).

The ether extract intake by cows at mid-lactation was $17.14 \%$ lower than the means at early and late lactation $(0.41 \mathrm{~kg} / \mathrm{day} ; \mathrm{P}=0.06)$. The non-fibrous carbohydrate intake (NFCI) in late lactation was $16.03 \%$ higher than in early and mid-lactation (4.02kg/day; $\mathrm{P}=0.04)$. There was no difference in total digestible nutrient intake (TDNI; $\mathrm{P}>0.10$ ) and dry matter digestibility (DMD; $\mathrm{P}=0.02$ ) between early and late lactation (mean of $9.05 \mathrm{~kg} /$ day and $62.37 \%$, respectively).

The digestibility of crude protein (DCP; $\mathrm{P}<0.01$ ) and ether extract (DEE; $\mathrm{P}=0,04)$ in early lactation was $12.97 \%$ and $5.03 \%$ higher than in other stages, averaging $54.27 \%$ and $82.01 \%$, respectively. There was no difference $(\mathrm{P}=0.73)$ between lactation stages on $\mathrm{N}$-ingested (mean of $234.46 \mathrm{~g} /$ day). The excretion of $\mathrm{N}$ in milk $(\mathrm{P}=0.01)$ and urine $(\mathrm{P}<0.01)$ was higher in early lactation than in other stages (Table 3 ). The nitrogen balance in late lactation was $123.5 \%$ higher than in early lactation (mean of -4.66 g/day). 
Table 2. Nutrient intake and digestibility in F1 Holstein/Zebu cows at different lactation stages

\begin{tabular}{|c|c|c|c|c|c|}
\hline \multirow{2}{*}{ Item $^{1}$} & \multicolumn{3}{|c|}{ Lactation stage (days) $^{2}$} & \multirow{2}{*}{ SEM $^{3}$} & \multirow{2}{*}{ P-value } \\
\hline & Early & Mid & Late & & \\
\hline & Intake & & & & \\
\hline Dry matter, $\mathrm{kg} /$ day & $13.72 \mathrm{ab}$ & $13.27 b$ & $14.37 \mathrm{a}$ & 0.70 & 0.01 \\
\hline Dry matter, \% BW & $2.84 \mathrm{ab}$ & $2.75 b$ & $2.98 \mathrm{a}$ & 0.12 & 0.01 \\
\hline Crude protein, $\mathrm{kg}$ /day & 1.46 & 1.46 & 1.50 & 0.07 & 0.93 \\
\hline Ether extract, kg/day & $0.42 \mathrm{a}$ & $0.35 b$ & $0.41 \mathrm{a}$ & 0.02 & 0.06 \\
\hline Non-fibrous carbohydrates, $\mathrm{kg} /$ day & $4.28 \mathrm{~b}$ & $4.15 b$ & $5.02 \mathrm{a}$ & 0.25 & 0.04 \\
\hline $\mathrm{NDF}_{\mathrm{CP}}, \mathrm{kg} /$ day & 6.97 & 6.67 & 6.72 & 0.31 & 0.78 \\
\hline $\mathrm{NDF}_{\mathrm{CP}}, \% \mathrm{BW}$ & 1.44 & 1.38 & 1.39 & 0.05 & 0.52 \\
\hline \multirow{2}{*}{ TDN, kg/day } & $9.00 \mathrm{a}$ & $7.99 \mathrm{~b}$ & $9.10 \mathrm{a}$ & 0.36 & 0.07 \\
\hline & \multicolumn{3}{|c|}{ Nutrient digestibility (\%) } & & \\
\hline Dry matter & $63.22 \mathrm{a}$ & $57.91 \mathrm{~b}$ & $61.53 \mathrm{a}$ & 1.24 & 0.02 \\
\hline Crude protein & $62.36 \mathrm{a}$ & $53.09 \mathrm{~b}$ & $55.45 b$ & 1.74 & $<0.01$ \\
\hline Ether extract & $86.36 \mathrm{a}$ & $82.16 b$ & $81.87 b$ & 1.32 & 0.04 \\
\hline Non-fibrous carbohydrates & 77.37 & 75.62 & 78.13 & 1.67 & 0.56 \\
\hline $\mathrm{NDF}_{\mathrm{AP}}$ & 56.64 & 53.92 & 53.71 & 1.13 & 0.14 \\
\hline TDN & $65.88 \mathrm{a}$ & $60.85 b$ & $63.43 \mathrm{ab}$ & 1.12 & 0.01 \\
\hline
\end{tabular}

${ }^{1}$ NDFap - neutral detergent fiber corrected for ash and protein; TDN - total digestible nutrients; BW - body weight. ${ }^{2}$ Lactation stage: Early, 50 \pm 12.80 days; Mid, $111.5 \pm 11.75$ days; and Late lactation, $183 \pm 17.25$ days. Means followed by equal letters do not differ by Student-Newman-Keuls test (SNK; P>0.05)

${ }^{3} \mathrm{SEM}$ - standard error of the mean.

${ }^{4} \mathrm{P}-$ Probability.

Table 3. Balance and nitrogen use efficiency in crossbred F1 Holstein/Zebu cows at different lactation stages

\begin{tabular}{|c|c|c|c|c|c|}
\hline \multirow{2}{*}{ Item $^{1}$} & \multicolumn{3}{|c|}{ Lactation stage (days) $^{2}$} & \multirow{2}{*}{$\mathrm{SEM}^{3}$} & \multirow{2}{*}{ P-value ${ }^{4}$} \\
\hline & Early & Mid & Late & & \\
\hline $\mathrm{N}$-ingested, g/day & 234.42 & 242.59 & 226.39 & 14.37 & 0.73 \\
\hline N-milk, g/day & $69.40 \mathrm{a}$ & $60.52 \mathrm{~b}$ & $55.12 \mathrm{~b}$ & 3.05 & 0.01 \\
\hline $\mathrm{N}$-feces, g/day & 89.67 & 114.54 & 102.64 & 9.17 & 0.17 \\
\hline $\mathrm{N}$-urine, g/day & $80.02 \mathrm{a}$ & $60.43 \mathrm{~b}$ & $48.80 \mathrm{~b}$ & 4.70 & $<0.01$ \\
\hline Nitrogen balance, g/day & $-4.66 b$ & $7.09 \mathrm{ab}$ & $19.82 \mathrm{a}$ & 6.89 & 0.06 \\
\hline $\mathrm{NUE}^{5}$ & $0.301 \mathrm{a}$ & $0.253 \mathrm{~b}$ & $0.246 \mathrm{~b}$ & 0.01 & $<0.01$ \\
\hline UUN, mg/dL & $10.55 \mathrm{a}$ & $9.44 \mathrm{a}$ & $6.89 b$ & 1.09 & 0.07 \\
\hline PUN, mg/dL & $21.82 \mathrm{a}$ & $14.52 \mathrm{~b}$ & $13.09 \mathrm{~b}$ & 0.52 & $<0.01$ \\
\hline MUN, mg/dL & $14.76 \mathrm{a}$ & $15.15 \mathrm{a}$ & $12.18 \mathrm{~b}$ & 0.60 & $<0.01$ \\
\hline
\end{tabular}

${ }^{1} \mathrm{~N}$ - nitrogen; BW - body weight; NUE - Nitrogen use efficiency; UUN - urine urea nitrogen; PUN - plasma urea nitrogen; MUN - milk urea nitrogen.

${ }^{2}$ Lactation stage: Early, 50 \pm 12.80 days; Mid, $111.5 \pm 11.75$ days; and Late lactation, $183 \pm 17.25$ days. Means followed by equal letters do not differ by Student-Newman-Keuls test (SNK; P>0.05)

${ }^{3} \mathrm{SEM}$ - standard error of the mean.

${ }^{4} \mathrm{P}-$ Probability.

Cows in early lactation were $17.10 \%$ more efficient in terms of nitrogen use than cows in other lactation stages (mean of $0.25 ; \mathrm{P}<0.01$ ). The excretion of plasma nitrogen was higher in early lactation compared with other stages (mean of $18.17 \mathrm{mg} / \mathrm{dL} ; \mathrm{P}<0.01)$. The feeding time of cows was not affected $(\mathrm{P}=0.30)$ by lactation stage, with a mean of 5.02 hours/day (Table 4). Cows in early lactation spent an additional 1.31 hours/day ruminating compared with other stages (mean 6.87 hour/day; $\mathrm{P}<0.01$ ). The resting time in late lactation was $18.37 \%$ higher than in early lactation (10.13 hour/day; $\mathrm{P}=0.05)$. 
Table 4. Feeding behavior of F1 Holstein/Zebu cows at different lactation stages

\begin{tabular}{|c|c|c|c|c|c|}
\hline \multirow{2}{*}{ Item } & \multicolumn{3}{|c|}{ 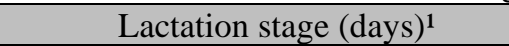 } & \multirow{2}{*}{$\mathrm{SEM}^{2}$} & \multirow{2}{*}{ P-value ${ }^{3}$} \\
\hline & Early & Mid & Late & & \\
\hline Feeding, hour/day & 5.66 & 4.91 & 4.50 & 0.52 & 0.30 \\
\hline Ruminating, hour/day & $8.20 \mathrm{a}$ & $6.88 \mathrm{~b}$ & $6.87 \mathrm{~b}$ & 0.32 & 0.01 \\
\hline Resting, hour/day & $10.13 b$ & $12.20 \mathrm{a}$ & $12.62 \mathrm{a}$ & 0.73 & 0.05 \\
\hline Chewing & & & & & \\
\hline number/bolus & 53.21 & 45.85 & 52.04 & 3.46 & 0.28 \\
\hline number/min & $60.05 \mathrm{~b}$ & $66.68 \mathrm{a}$ & $63.85 \mathrm{ab}$ & 1.4 & $<0.01$ \\
\hline hours/day & $13.86 \mathrm{a}$ & $11.79 \mathrm{~b}$ & $11.37 \mathrm{~b}$ & 0.73 & 0.05 \\
\hline Feeding efficiency DM, g/hour & 2569 & 3125 & 3278 & 246 & 0.11 \\
\hline Ruminating efficiency DM, g/hour & $1711 \mathrm{~b}$ & $2008 \mathrm{a}$ & $1974 \mathrm{a}$ & 95 & 0.06 \\
\hline
\end{tabular}

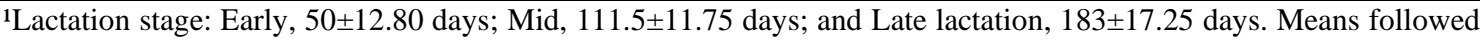
by equal letters do not differ by Student-Newman-Keuls test (SNK; P>0.05)

${ }^{2} \mathrm{SEM}$ - standard error of the mean.

${ }^{3} \mathrm{P}-$ Probability.

Regardless of the lactation stage, the number of chews per bolus was $50.36(\mathrm{P}=0.28)$. There were more chews in mid-lactation, averaging 66.68 chews/minute $(\mathrm{P}<0.01)$. In early lactation, the cows spent an additional 2.28 hours/day chewing compared with other stages (mean of 11.58 hours/day; $\mathrm{P}=0.05$ ). There was no difference in feeding efficiency of DM $(\mathrm{P}=0.11)$. The highest rumination efficiency of $\mathrm{DM}$ was observed in mid-lactation $(\mathrm{P}=0.06)$.
Milk yield $(\mathrm{P}<0.01)$ was $24.17 \%$ higher in early lactation than in other stages (mean of $11.02 \mathrm{~kg} /$ day; Table 5). The lowest $3.5 \%$ fatcorrected milk yield was observed in late lactation $(\mathrm{P}<0.01)$. The highest fat content and total solids in the milk were observed in mid-lactation, while the milk protein content was lowest in early lactation.

Table 5. Performance and feed efficiency of F1 Holstein/Zebu cows at different lactation stages

\begin{tabular}{|c|c|c|c|c|c|}
\hline \multirow{2}{*}{ Item } & \multicolumn{3}{|c|}{ Lactation stage (days) $^{1}$} & \multirow{2}{*}{$\mathrm{SEM}^{2}$} & \multirow{2}{*}{ P-value ${ }^{3}$} \\
\hline & Early & Mid & Late & & \\
\hline Milk yield, kg/day & $14.54 \mathrm{a}$ & $11.78 \mathrm{~b}$ & $10.27 \mathrm{~b}$ & 0.56 & $<0.01$ \\
\hline $3.5 \%$ fat-corrected milk yield, $\mathrm{kg} /$ day & $14.03 \mathrm{a}$ & $12.07 \mathrm{~b}$ & $9.37 \mathrm{c}$ & 0.54 & $<0.01$ \\
\hline Fat, (g/kg milk) & $33.1 \mathrm{ab}$ & $36.8 \mathrm{a}$ & $29.8 \mathrm{~b}$ & 2.00 & 0.06 \\
\hline Protein, (g/kg milk) & $30.4 \mathrm{a}$ & $33.1 \mathrm{~b}$ & $34.0 \mathrm{~b}$ & 0.90 & 0.03 \\
\hline Total solids, (g/kg milk) & $120.1 \mathrm{ab}$ & $127.0 \mathrm{a}$ & $118.8 b$ & 2.70 & 0.09 \\
\hline Final body weight, kg & $492.82 \mathrm{~b}$ & $465.63 \mathrm{c}$ & $504.90 \mathrm{a}$ & 4.90 & $<0.01$ \\
\hline Difference in body weight, $\mathrm{kg}$ & $6.99 \mathrm{a}$ & $-35.19 b$ & $52.57 \mathrm{a}$ & 12.50 & $<0.01$ \\
\hline Final body condition score & 3.79 & 3.83 & 3.69 & 0.06 & 0.32 \\
\hline Difference in body condition score & 0.15 & -0.02 & 0.13 & 0.06 & 0.16 \\
\hline Feed efficiency, $\mathrm{kg}$ of milk/kg of DM & $1.07 \mathrm{a}$ & $0.87 \mathrm{~b}$ & $0.77 \mathrm{~b}$ & 0.05 & $<0.01$ \\
\hline
\end{tabular}

${ }^{1}$ Lactation stage: Early, 50 \pm 12.80 days; Mid, $111.5 \pm 11.75$ days; and Late lactation, $183 \pm 17.25$ days. Means followed by equal letters do not differ by Student-Newman-Keuls test (SNK; P>0.05)

${ }^{2} \mathrm{SEM}$ - Standard error of the mean

${ }^{3} \mathrm{P}-$ Probability

The body weight of cows was lower in midlactation than in other stages. Cows in midlactation lost $(\mathrm{P}<0.01) 35.19 \mathrm{~kg}$ in relation to their initial weight. On the other hand, late-lactation cows gained $52.57 \mathrm{~kg}$ in relation to their initial body weight. There was no change in the body condition score (mean of $3.7 ; \mathrm{P}=0.32$ ). Cows in early lactation had a feed efficiency $23.36 \%$ higher compared with other lactation stages (mean of $0.82 \mathrm{~kg}$ of milk/kg of DM). 


\section{DISCUSSION}

Several physical and physiological changes occur during the transition period of dairy cows (from 21 days before to 21 days postpartum), modifying animal behavior. The fetus grows rapidly in the last 21 days of pregnancy, which consequently increases pressure on organs responsible for digestive and metabolic processes (i.e., rumen and liver), reducing the space available for feed (Franzoni et al., 2018). Concomitantly, there is also an increase in blood concentrations of estrogen, corticosteroids and reduction in concentrations of progesterone (Chew et al., 1979; Franzoni et al., 2018). The associations of these factors may reduce dry matter intake by up to $30 \%$, predisposing cows to a negative energy balance in early lactation, with consequent mobilization of energy reserves (Grum et al., 1996).

However, the DMI increases up to 75 days postpartum (characterized as limit for early lactation in pure Holstein cows) but the maximum DM intake occurs at mid-lactation, with reduction in the subsequent lactation stage (Gulay et al., 2003). In crossbred cows, especially F1 Holstein x Zebu, this behavior in the DMI seems to be less marked compared to pure Holstein cows since the DMI was $7.65 \%$ higher in late lactation compared with other stages (mean of $13.49 \mathrm{~kg} /$ day). Santos et al. $(2012,2014)$ observed a quadratic behavior of lactation stage on DMI in F1 Holstein $x$ Zebu cows kept on pasture, reaching its peak at 40 days post-partum (mean of $13.34 \mathrm{~kg} /$ day), while in this study the DMI was $13.72 \mathrm{~kg} /$ day using confined cows (dietary NDF of $498.26 \mathrm{~g} / \mathrm{kg} \mathrm{DM}$ ).

Even with intermediate DMI values, milk yield was $24.17 \%$ higher in early lactation compared with other stages (mean of $11.02 \mathrm{~kg} /$ day). In Holstein cows, milk yield also increases in early lactation (Gulay et al., 2003; Lopez et al., 2015), but there is a reduction in body weight. This increase in milk yield is linked to peak lactation, which occurs after $60 \pm 10$ days post-partum in Holstein cows (Keown et al., 1986; Gulay et al., 2003) and 30 \pm 8 days in F1 Holstein x Zebu cows (Santos et al., 2014). According to Forbes (1995), the level of intake is among the main factors affecting feed digestibility and milk production. The higher milk yield at early lactation may be related to greater nitrogen use efficiency, longer rumination time (8.20 hours/day) and chewing, which certainly favored particle size reduction of substrate in the rumen. Cows spent more time resting (12.41 hours) in mid and late lactation than in early lactation (10.13 hours). This response is associated with lactogenesis (level of prolactin), which occurs with greater intensity in early lactation (Lacasse et al., 2011; Ollier et al., 2013, 2014).

In this study, the lowest body weight was observed in cows at mid-lactation. According to Buckley et al. (2000), increased weight loss during the 45-day postpartum period is associated with expulsion of the fetus, placenta and other uterine contents, followed by gradual decrease in body weight due to mobilization of adipose tissues. It explains the lower body weight and beta-hydroxybutyrate (BHB) concentration in mid-lactation and, consequently, higher concentrations of non-esterified fatty acids (NEFA) (Lacasse et al., 2011). In Holstein cows, Bauman and Currie (1980) reported that energy from body fat stores can contribute to approximately $33 \%$ of milk production, explaining the higher productivity during the first 60 days of lactation. The catabolism of adipose tissue can support the production of 120 to $550 \mathrm{~kg}$ of milk during the first weeks of lactation. However, in F1 Holstein $x$ Zebu cows, the metabolism of adipose tissue was not significantly affected since there was no change in BCS, averaging 3.77 .

According to Ferreira et al. (2000), monitoring postpartum body weight in lactating cows is fundamental to ensure that body reserves will be adequate for cows to exhibit estrus and guarantee pregnancy. Furthermore, the authors reported that a BCS of 3.5 is ideal for cows to show estrus within 90 days postpartum. For this condition, it is necessary a body condition score above 3.0 in prepartum, or final third of lactation. In our study, the average BCS of 3.77 indicates that cows had sufficient energy reserves during lactation, which is a positive characteristic of F1 Holstein $\mathrm{x} Z \mathrm{Zebu}$ cows. Ferreira et al. (2000) reported that the desirable BCS in late lactation, close to the dry period of the cow, should be approximately 3.5, while at calving it should be 3.5 to 4.0 . This assessment in late lactation is essential to prevent some cows from becoming too thin at drying off. Under this condition, there is not enough time to regain the necessary body reserves during the dry 
period, aiming for a good body condition at calving (Ferreira et al. (2000).

Feed efficiency was improved in cows at early lactation due to higher milk yield and 3.5\%-fat corrected milk yield. The lowest $3.5 \%$-fat corrected milk yield was reported in late lactation, as well as lower amounts of fat and total solids in the milk. Evaluating the lactation curve in F1 Holstein x Zebu cows, Silva et al. (2015) and Glória et al. (2012) reported a reduction in milk yield in late lactation, which can be explained by the natural reduction in prolactin synthesis. Thus, in F1 Holstein x Zebu cows, Santana et al. (2019) recommended a restriction of dietary supply up to $2 \%$ of body weight (on dry matter basis) at this stage (late lactation) as a cost-reduction strategy.

\section{CONCLUSION}

F1 Holstein x Zebu cows have increased dry matter intake in late lactation. However, milk yield and feed efficiency in early lactation are benefited by changes in feeding behavior, such as increased rumination time.

\section{ACKNOWLEDGMENTS}

The authors thank the Foundation for Research Support of the State of Minas Gerais (FAPEMIG), the National Council for Scientific and Technological Development (CNPq), EPAMIG Felizlândia and Instituto Nacional de Ciência e Tecnologia (INCT - Ciência Animal). This study was financed in part by the Coordenação de Aperfeiçoamento de Pessoal de Nível Superior Brasil (CAPES) - Finance Code 001.

\section{REFERENCES}

ANUÁRIO leite 2018: Indicadores, tendências e oportunidades para quem vive no setor leiteiro. Disponível em https://www.embrapa.br/buscade-publicacoes/-/publicacao/1094149/anuarioleite-2018-indicadores-tendencias-eoportunidades-para-quem-vive-no-setor-leiteiro. Acessado em Julho de 2019.

BAUMAN, D.E.; CURRIE, W.B. Partitioning of nutrients during pregnancy and lactation: A review of mechanisms involving homeostasis and homeorhesis. J. Dairy Sci., v.63, p.1514-1529, 1980 .
BORGES, L.D.A.; ROCHA JÚNIOR, V.R.; MONÇÃO, F.P. et al. Nutritional and productive parameters of Holstein/Zebu cows fed diets containing cactus pear. Asian Australas. J. Anim. Sci., v.32, p.1373-1380, 2019.

BÜRGER, P.J.; PEREIRA, J.C.; QUEIROZ, A.C. et al. Ingestive behavior in Holstein calves fed diets with different concentrate levels. Braz. J. Anim. Sci., v.29, p.236-242, 2000.

BUCKLEY, F.; DILLON, P.; RATH, M. et al. The relationship between genetic merit for yield and live weight, condition score, and energy balance of spring calving holstein friesian dairy cows on grass based systems of milk production. J. Dairy Sci., v.83, p.1878-1886, 2000.

KEOWN, J.F.; EVERETT, R.W.; EMPET, N.B. et al. Lactation curves. J. Dairy Sci., v.69, p.769$781,1986$.

CHEW, B.P.; ERB, R.E.; FESSLER, J.F. et al. Effects of ovariectomy during pregnancy and of prematurely induced parturition on progesterone, estrogen and calving traits. J. Dairy Sci., v.62, p.557-566, 1979.

CHIZZOTTI M.L.; VALADARES FILHO, S.C.; VALADARES. R.F.D. et al. Intake, digestibility and nitrogen metabolism in Holstein cows with different milk production levels. Braz. J. Anim. Sci., v.36, p.138-146, 2007.

DALTRO, D.S.; PADILHA, A.H.; SILVA, M.V.G.B. Heterosis in the lactation curves of Girolando cows with emphasis on variations of the individual curves. J. Appl. Anim. Res., v.47, p.85-95, 2019.

DETMANN, E.; SOUZA, M.A.; VALADARES FILHO, S.C. et al. Métodos para análise de alimentos. Visconde do Rio Branco, MG: Suprema, 2012. 214p.

FERREIRA, A.M.; VIANA, J.H.M.; SÁ, W.F. et al. Restrição alimentar e atividade ovariana luteal cíclica pós-parto em vacas girolanda. Pes. Agropec. Bras., v. 35, p.2521-2528, 2000.

FORBES, J.M. Voluntary food intake and diet selection in farm animals. Oxon: CAB International, 1995.

FRANZONI, A.P.S.; GLORIA, J.R.; COSTA, A.L.B.S.A. et al. Metabolic and hormone profiles of Holstein $x$ Gyr cows during pre- and postpartum. Pesqui. Agropecu. Bras., v.53, p.371$377,2018$. 
GLÓRIA， J.R.; BERGMANN， J.A.G.; QUIRINO, C.R. et al. Environmental and genetic effects on the lactation curves of four genetic groups of crossbred Holstein-Zebu cows. R. Bras. Zootec., v.41, p.2309-2315, 2012.

GULAY, M.S.; HAYEN, M.J.; BACHMAN, K.C. et al. Milk production and feed intake of holstein cows given short (30-d) or normal (60-d) dry periods. J. Dairy Sci., v.86, p.2030-2038, 2003.

GRUM, D.E.; DRACKLEY, J.K.; YOUNKER, R.S. Nutrition during the dry period and hepatic lipid metabolism of periparturient dairy cows. J. Dairy Sci. v.79, p.1850-1864, 1996.

LACASSE, P.; V.; LOLLIVIER, R.M.; BRUCKMAIER, Y.R. et al. Effect of the prolactin-release inhibitor quinagolide on lactating dairy cows. J. Dairy Sci., v.94, p.13021309, 2011.

LICITRA, G.; HERNANDEZ, T.M.; VAN SOEST, P.J. Standartization of procedures for nitrogen fractionation of ruminants feeds. Anim. Feed Sci. Technol., v.57, p.347-58, 1996.

LÓPEZ, S.; FRANCE, J.; ODONGO, N.E. et al. On the analysis of Canadian Holstein dairy cow lactation curves using standard growth functions. J. Dairy Sci., v.98, p.2701-2712, 2015.

SANTANA, P.F.; ROCHA JÚNIOR, V.R.; RUAS, J.R.M. et al. Feed restriction of F1 Holstein $\times$ Zebu cows in the final third of lactation modifies intake, nutrient digestibility, feeding behavior, and performance. R. Bras. Zootec., 48:e20180130, 2019.

SILVA, D.A.; ROCHA JÚNIOR, V.R.; RUAS, J.R.M. Chemical and fatty acid composition of milk from crossbred cows subjected to feed restriction. Pes. Agropec. Bras., v. 54, p. e00051, 2019.

MERTENS, D.R. Gravimetric determination of amylase-treated neutral detergent fiber in feeds with refluxing in beaker or crucibles: collaborative study. J. AOAC Int., v.85, p.12171240, 2002.

MEZZALIRA, J.C.; CARVALHO, P.C.F.; FONSECA, L. et al. Methodological aspects of ingestive behavior of grazing cattle. Braz. J. Anim. Sci., v.40, p.1114-1120, 2011.
MISHRA, S.; KUMARI, K.; DUBEY, A. Body condition scoring of dairy cattle: a review. Res. Rev. J. Vet. Sci., v.2, p.58-65, 2016.

MONÇÃO, F.P.; COSTA, M.A.M.; RIGUEIRA, J.P. et al. Productivity and nutritional value of BRS capiaçu grass (Pennisetum purpureum) managed at four regrowth ages in a semiarid region. Trop. Anim. Health Prod., v.51, p.1-7, 2019.

NUTRIENT requirements of dairy cattle. 7.ed. Washington, DC: National Academy Press; 2001.

OFFICIAL methods of analysis. 12.ed. Washington, D.C.: AOAC, 1990. 1094p.

OLLIER, S.; ZHAO, X.; LACASSE, P. Effect of prolactin-release inhibition on milk production and mammary gland involution at drying-off in cows. J. Dairy Sci., v.96, p.335-343, 2013.

OLLIER, S.; ZHAO, X.; LACASSE, P. Effects of feed restriction and prolactin-release inhibition at drying off on metabolism and mammary gland involution in cows. J. Dairy Sci., v.97, p.49424954, 2014.

SALGADO, L.F.F.; CRUZ, T.M.S.; TAKATANI, H. A raça Girolando: história, evolução e importância no cenário da pecuária leiteira nacional. Bol. Téc., n.19, 14p., 2016. (Produção Animal UNIBRASIL).

SANTOS, S.A.; VALADARES FILHO, S.C.; DETMANN, E. et al. Intake, digestibility and nitrogen use efficiency in crossbred F1 Holstein $\times$ Zebu grazing cows. Rev. Bras. Zootec., v.41, p.1025-1034, 2012.

SANTOS, S.A.; VALADARES FILHO, S.C.; DETMANN, E. et al. Intake, milk production and weight change curves for lactating Holstein $\mathrm{x}$ Zebu cows under grazing. Arq. Bras. Med. Vet. Zootec., v.66, p.827-836, 2014.

SAS/STAT 9.2 user's guide. Cary: SAS Institute, Inc., 2008.

SILVA, M.V.G.B.; CANAZO-CAYO, A.W.; LOPES, O.S. et al. Programa de Melhoramento Genético da Raça Girolando: do teste de progênie às avaliações genômicas. Inf. Agropecu., v.36, p.35-40, 2015. 
SKLAN, D.; ASHKENAZI, R.; BRAUN, A. et al. Fatty acids, calcium soaps of fatty acids and cottonseeds fed to high yielding cows. J. Dairy Sci., v.75, p.2463-2472, 1992.

VALADARES FILHO, S.C.; BRODERICK, G.A.; VALADARES, R.F. et al. Effect of replacing alfalfa silage with high moisture corn on nutrient utilization and milk production. J Dairy Sci., v.83, p.106-114, 2000.
VAN SOEST, P.J.; ROBERTSON, J.B.; LEWIS, B.A. Symposium: carbohydrate methodology, and nutritional implications in dairy cattle. $J$. Dairy Sci., v. 74, p. 3583-3597, 1991. 